The University of Akron

\title{
IdeaExchange@UAkron
}

Proceedings from the Document Academy

University of Akron Press Managed

December 2017

\section{Science Serving Industry: Documentary Authority and Industrial Influence in 19th Century American Chemistry}

Shawn Martin

Indiana University - Bloomington, shawn.j.martin@dartmouth.edu

Please take a moment to share how this work helps you through this survey. Your feedback will be important as we plan further development of our repository.

Follow this and additional works at: https://ideaexchange.uakron.edu/docam

Part of the History of Science, Technology, and Medicine Commons, $\underline{\text { Scholarly Communication }}$ $\underline{\text { Commons, and the Scholarly Publishing Commons }}$

\section{Recommended Citation}

Martin, Shawn (2017) "Science Serving Industry: Documentary Authority and Industrial Influence in 19th Century American Chemistry," Proceedings from the Document Academy: Vol. 4 : Iss. 2 , Article 4.

DOI: https://doi.org/10.35492/docam/4/2/4

Available at: https://ideaexchange.uakron.edu/docam/vol4/iss2/4

This Conference Proceeding is brought to you for free and open access by University of Akron Press Managed at IdeaExchange@UAkron, the institutional repository of The University of Akron in Akron, Ohio, USA. It has been accepted for inclusion in Proceedings from the Document Academy by an authorized administrator of

IdeaExchange@UAkron.For more information, please contact mjon@uakron.edu, uapress@uakron.edu. 


\section{Introduction}

Science in the early part of $19^{\text {th }}$-century America was, compared to other countries in Europe, largely unorganized. Prior to the U. S. Civil War, there was only one scientific journal, the American Journal of Science, one scientific society, the American Association for the Advancement of Science, and a handful of influential universities, many of which were located in three cities: Philadelphia, Boston, and New York (Baatz, 1991). In contrast, Europe had over 650 such societies and academies founded in the 18th century, including very specialized groups focusing on chemistry or natural history (Philips, 2016), and many of these societies were also heavily involved in publishing scientific periodicals (Kronick, 1976). Thus, with its relative dearth of scientific societies and related publications, one would think that the United States during this time period would not be the best case study for investigating documentation of science. Despite the apparent lack of scientific organization and publication in the United States, American scientists were quite eager to advance their work and in the late 19th century, they were in fact celebrating their progress.

In an article celebrating the centennial of the field of chemistry's "birth" in the United States in 1874, J. Lawrence Smith (1874), formerly president of the American Association for the Advancement of Science, later president of the American Chemical Society (one of the first specialized professional scientific associations created in the United States), and one of the most influential figures in science during the mid-19th century, wrote: "In our days a useful discovery is scarcely made, or a happy application of one found out before it is published, described in the scientific journals, or other technical periodicals." Smith went on to say that such efforts are important because from them it is possible to support "industry which has no sooner sprung into existence than it becomes important and prosperous" (p. 70). What is important to note here is Smith's recognition of two attributes of chemistry in the late 19th century. First, Smith suggests that whenever scientific discoveries are made, they are almost immediately written down in scientific journals. Second, the information provided in these periodicals helps to promote the progress of industry. Therefore, at least for Smith, the document, in this case a scientific journal article, had a certain power in American society at that time, though Smith does not articulate what that power is or how it came to be. The question is, why did Smith believe this? Moreover, is it possible to explain Smith's underlying assumptions about the connection between scientific periodicals and industry? By looking at the society in which Smith lived, the nascent scientific institutions in the United States during the late 19th century, and the documents (journals) that these social organizations produced, it may be possible to provide some preliminary answers to those questions. 


\section{Philosophy of Chemistry}

One possible framework for understanding the assumptions of Smith lies within his own field: chemistry. Within the philosophy of chemistry, there is a body of literature that can help to understand documentation practices within that science. One well-known philosopher of chemistry, Rom Harré (2014), has argued:

Adopting the concept of 'affordance' to analyze the nature of chemical studies, it becomes clear that chemical 'facts' are attributes not of an independent world revealed by the use of apparatus, but are dispositional properties of a hybrid entity and indissoluble union of apparatus, experimenter, and world. (p. 79)

Thus, Harré provides a framework whereby one can understand the field of chemical documentation. Drawing on the idea of affordances from J. J. Gibson (1967), Harré first provides three affordances for investigation, including what he terms "world," or the overall philosophical blueprint in which scientists of the time operated, or in Gibson's terms, a cultural affordance. Second, Harré discusses a kind of social affordance that he terms "experimenter," the individual actors within a larger social system of other scientists. Finally, Harré calls "apparatus" or what one might call a material affordance, which in the case of chemistry journals would be the articles themselves, the apparatus chemists use to communicate results. Utilizing Harré's framework can help to better understand Smith's underlying assertion that documentation and industrial production are at the core of $19^{\text {th }}$ century chemistry.

For Harré, the way to identify affordances are by utilizing what he terms "hinge mechanisms," which he defined as hidden mechanisms that are not necessarily apparent to the individuals who utilize them (Harré, 2014, p. 82). According to Harré, utilizing such hinge mechanisms "reveal status of scientific discourses that describe not only observable phenomena but also possible phenomena that are beyond the reach of even the enhanced senses" (p. 85). Most importantly, for Harré, both affordances and hinge mechanisms are related, particularly in the case of chemistry, because:

[T] he core of chemistry as a science is an open repertoire of practices, and what executing them affords. Affordances are attributes of hybrid beings, indissoluble groupings of material stuff into apparatus/world complexes, including the people who manage and manipulate them. (p. 88) 


\section{Historical Background}

Before applying these frameworks, however, it is important to understand some of the historical context of American science and chemistry. In the early to mid-19 century, scientific activity in the United States was limited, and there were very few nationally coordinated scientific enterprises. The American Philosophical Society, founded in 1746 and dedicated to all intellectual pursuits, served as the de facto national organization for many scientists. Additionally, there were local groups, often headquartered at local scientific institutions such as museums or at universities. Examples of such organizations would include the Academy of Natural Science in Philadelphia, or the Lyceum of Natural History in New York. In 1848, the American Association for the Advancement of Science was founded as the first national scientific organization. Though it technically represented all sciences, the American Association for the Advancement of Science grew out of the Association of American Geologists, and was most interested in finding ways to exploit the rich geological and mineralogical resources of the United States. The United States government was not heavily involved in scientific research at this time, and in the cases where it was, the government was interested largely in surveying, such as the U.S. Coastal Survey, and observatories for the purpose of weather observation. Some of the early projects of the Smithsonian Institution (founded in 1846) were actually a part of this larger government project to benefit both navigation and agriculture. It was not until after the Civil War that the National Academy of Sciences was formed and the government became more heavily involved in scientific research (Oleson and Brown, 1976).

Some of these organizations, like the American Philosophical Society, published proceedings of their meetings. Additionally, some of the local associations associated with museums or universities also produced journals, though many of them were limited only to members of those organizations, and thus were focused locally and not nationally. There was only one scientific research journal with a national scope starting in 1818, the American Journal of Science, founded by Benjamin Silliman of Yale University. As with the case of the American Association for the Advancement of Science, this journal was dedicated to all of the sciences (and in its early years even the arts). But in reality, as Silliman (1818) himself says in his introduction:

[The journal] will be a leading object to illustrate American Natural History, and especially our Mineralogy and Geology. The applications of these sciences are obviously as numerous as physical arts and physical wants; for one of these arts or wants can be named which is not connected with them. (p. v). 
Therefore, the journal also had a practical aspect, similar to both the National Association and the government projects at the time.

There was not a single dedicated association for chemistry until the later part of the 19th century. The American Chemical Society was founded in 1876. The inaugural event for the society's founding was a conference in 1874 that commemorated the centennial of Joseph Priestley's discovery of oxygen in 1774. At that meeting, several attendees debated the possibility of creating a new society dedicated to chemistry. Two years later, C. F. Chandler, professor at Columbia University, called together the first meeting of the American Chemical Society (Browne and Weeks, 1952). The Journal of the American Chemical Society began in 1879, though it had been published as the Proceedings of the American Chemical Society since 1876. Later, the journal absorbed several other journals, such as the Journal of Analytical and Applied Chemistry, so that by the beginning of the 20th century, it was by far one of the largest chemistry journals. The preeminence of this organization and its journal was not a foregone conclusion, however. There were other local chemical associations and also a subsection for chemistry within the American Association for the Advancement of Science. It was not until 1897 that many of these organizations finally merged with the larger association and the smaller journals.

\section{Cultural Affordances: "World"}

With this historical background in mind, it may be helpful to think of the cultural affordances or the "world," to use Harré's term, in which the field of chemistry was developing in $19^{\text {th }}$-century United States. In some ways, scientists in the United States tried to tie themselves to a much earlier European tradition of scientific endeavor. In other ways the scientific and chemical institutions within the United States were quite different from its European counterparts. These differences led to a distinctive kind of cultural context in which American scientists searched both for authority and the ways in which they saw their documents (such as articles) serving the cause of American science.

One primary difference between the United States and Europe lay in its higher education system. About 20 years after Franklin and his contemporaries founded the American Philosophical Society, Wilhelm von Humboldt wrote his Theory of Human Education that led to the reform of German universities and public education. These universities became instruments of the state. Unlike their American counterparts, German professors were employees of the state and subject to the kinds of bureaucratic control that the state could provide (Clark, 2006). In the United States, however, colleges and universities were run by a variety of different entities in the early 19th century-some religious, some secular, and some even quasi-state run. By the 1860s, however, through public education reform in the United States and legislation such as the Morrill Land Grant Act, higher 
education in the United States did have an element of the state-run bureaucracy, similar to that in Germany, on which the United States partially modeled its own system of both public and higher education (Guralnick, 1979).

Some scholars have suggested that science is fundamentally about control, whether of knowledge or of its application (Whitley, 1984). The kinds of developments within the United States (2008) with education and scientific philosophy have led historians of science, such as Steven Shapin to remark, "What the state wanted, and what it increasingly could secure from scientifically trained practitioners was not natural philosophy but instrumental expertise, not knowledge, but knowledge-power, not Truth but competence in predicting and controlling." Thus, according to Shapin, "the links between the state, commerce, and natural knowledge had crucial bearings on appreciations of the identity of both the man of science and scientific knowledge" (p. 39-40). Similarly, Robert Kargon and Scott Knowles (2002), writing about the development of scientific education in the 19th century, stated that this period was critical "in the relationship between science and practice, with theoretical knowledge, especially in electro-magnetism and organic chemistry, yielding profits and products through new manufacturing techniques and organized industrial research" (p. 1). Thus, it seems that the key difference between Europe and the United States is first and foremost an emphasis on usefulness, and a key to such usefulness was service to industry.

One can see this link between science and industry coming across quite clearly in statements from some of the early leaders in the American Association for the Advancement of Science. The vice president of chemistry section for the association, Harvey Wiley in the Proceedings of the American Association for the Advancement of Science (1886), wrote that, "Men of affairs often criticise science because it is not practical. . . I desire to say a few words respecting the economic aspects of Agricultural Chemistry" (p. 125). His address then discusses the impact of chemistry on the farming industry. Chemistry itself was no different; two years later, the Journal of the American Chemical Society (Breneman, 1888) reported "the outcome of the visit of the Society of Chemical Industry to the works of the above-mentioned company [Noble's Explosives Company]," and the journal often included entire sections dedicated to industrial chemistry (p. 116). According to Silliman (1886), Smith, former president of the American Association for the Advancement of Science and the American Chemical Society, "established a laboratory for the production of chemical reagents and of the rarer pharmaceutical preparations, in which enterprise he associated himself with Dr. E. R. Squibb, whose fame as a successful worker in pharmaceutical chemistry is well known" (p. 235). 


\section{Social Affordances: "Experimenter"}

With this overall idea that knowledge had to be useful to society and moreover useful to industry, it is important to look at the next step of how science generally and chemistry specifically organized in the late 19th century. John William Draper , the inaugural president of the American Chemical Society and a professor at New York University, said in his presidential address to the association that "The progress of science among us very largely depends on two elements: First, on our educational establishments. Second on our scientific societies" (American Chemical Society, 1876, p. 135). Furthermore, Draper went on to discuss the influence of associations like the American Philosophical Society and the American Association for the Advancement of Science. Moreover, Draper had suggestions for the way in which educational institutions, such as the one where he worked, and associations like the one he was leading ought to move forward in the future. In the conclusion to his address, Draper encouraged universities to abandon the practice of teaching Latin and Greek and to pursue a "modern" course which embraced science. By looking at the ways in which both scientific schools and scholarly societies advanced in the 19th century, one can see that the overall cultural affordances prevalent in the United States at the time permeated the social affordances in significant ways.

This growth of schools, however, led many scientific leaders to bemoan the fact that many universities were not teaching science appropriately. Smith in the Proceedings of the American Association for the Advancement of Science (1873) for instance bemoaned the many sub-par institutions, "our universities (or rather our so-called universities) are too numerous. Nowadays every college must have a scientific school attached.... it would be far better to have fewer scientific schools" (p. 3). The reason Smith advocated for this reduction of scientific schools, according to Silliman (1874), was because fields like chemistry were "usually coupled with natural philosophy and natural history, and was never made the subject of personal laboratory training other than by didactic and demonstrative lectures" and that "the incumbents of professorial chairs made no contributions to the advancement of science or the stock of human knowledge" (p. 92). At least for Smith, it seems not only was it important to have scientific education, but it was also important to have the right kind of scientific education in a laboratory with a professor who advanced practical knowledge, not the kinds of speculations found in natural philosophy.

Smith's ideas found receptive audiences around the United States, particularly in places where there was rapid industrialization (Kargon et al., 2002). At the same time, these scientific schools were rapidly changing their curricula in a practically oriented direction in order to meet the needs of economic development. 
Additionally, as the needs of industry increased, governments in both the United States and Europe also encouraged a rapid penetration of market values and ideologies into the universities that they either controlled directly or through subsidies. In all, during the 19th century, the expansion of industrial needs, population growth, and perceived opportunities for growth led to rapid changes within both the field of teaching, the curricula taught, and, perhaps more importantly, to the kinds of research that these teachers were encouraged to pursue (Clark, 2006).

\section{Material Affordances: "Apparatus"}

For the purposes of $19^{\text {th }}$-century chemistry, the "apparatus," to use Harré's term, or the material affordances, are particularly important for the future functioning not only of the academic scientific enterprise but also for the industrial initiatives that too rely on the professors who are teaching students within the larger higher education system. When Silliman (1874) wrote a second essay continuing his history of chemistry, he included a list of what he considered important articles documenting particular discoveries (p. 195-209). Silliman's emphasis on documentation seems to follow Whewell's emphasis. Thus, documentation, the material artifact of science, retains a primary importance in the system of communication. The question is, how can one interpret these documents in light of the larger cultural and social affordances in which they exist?

Alan G. Gross, Joseph E. Harmon, and Michael Reidy (2002) have studied the rhetoric of scientific writing and have noticed two particularly important changes in scientific writing over the period of the 19th century. First, the field becomes interested in establishing the concept of "fact"-what science can do to establish laws, principles, and methods that constitute something being definitively known. Prior to the 19th century, science was interested more in philosophical speculations that tried to relate scientific observations to religious or social theories about the nature of the world. In the 19th century that changed, so that scientists were not interested as much in proving philosophical precepts, but were more interested in establishing ideas that could be determined as definitively true. Furthermore, the method for establishing these facts is through the process of experimentation and quantitatively measuring observed phenomena in nature.

Second, and somewhat ironically considering the first move away from philosophical speculations, the field shifts from what was initially a science of description into a field of theory. Therefore, the sciences were interested in determining causes of phenomena. These causes were, however, different from the kinds of causes determined by scientists in the 18th century. The causes scientists strove to achieve were determined by observable facts, not by a priori philosophical suppositions. For physics and chemistry specifically, "the move is steadily in the 
direction of turning qualitative into quantitative facts and in creating a permanent reciprocity between experiment and theory" (Gross et al., 2002, p. 159-160).

Harré ties these larger themes identified by Gross et al. into his more generalized theories about affordances within chemistry. By drawing on ideas from both Wittgenstein's theories on hinge-practices (a supposition that precedes from a certainty) and mereology (a relation between the whole and the parts), Harré argues that chemists are able to theorize more effectively when they limit themselves to only parts of a whole. By doing so, they are able to create more effective models through inferences about a rather limited set of observations. According to Harré (2014), "The evidence for these inferences comes from the affordances which are disciplined with respect to realist or heuristic interpretations by attention to hingepractice and hinge-proposition pairs which incorporate the working metaphysics of an era" (p. 89). Thus, according to Harré, it seems that modern philosophy of chemistry is a kind of extension of some of the earlier trends identified by Gross et al.

In his presidential address, Smith reflects many of these changes identified by Gross et al. and by Harré. Smith (1873) tells his fellow scientists that "science is only an accurate record of the processes of nature; that its laws are only generalizations of its observations, and not a declaration of an inherent necessity; and that one of its observations is the uniformity of natural sequence" (p. 8). Furthermore, Smith criticizes Charles Darwin not on his observations on evolution, but rather suggests that Darwin has gone too far in making philosophical speculations about his observations. According to Smith, Darwin should have stayed with making observations of natural phenomena and not "stretching inferences from a few observations into a wide field" (p. 15). Thus, in the same ways that Gross et al. suggest that scientific genres are changing in the 19th century away from philosophical speculation to theorizing based on natural observation, so too does Smith, a prominent scientist, reflect their observations in the context of both chemistry and late $19^{\text {th }}$-century science.

\section{Conclusion}

In the closing of Harré's (2014) assessment of the philosophy of chemistry, he suggests that "some iconic or representational models were taken to be verisimilitudinous representations of unobservable entities, properties, processes, and mechanisms, others served only a heuristic function" (p. 86). To put that another way, the affordances (world, experimenter, and apparatus) reflect themselves in the theoretical models that chemists produce in the 21 st century. It is also true that the same models being produced by chemists of the 19th century served similar functions. These earlier documents produced in journals like the American Journal of Science and later in the Journal of the American Chemical Society were also representations of a much larger social structure that provides 
historians of science a way to investigate the underlying assumptions of the scientific project in the United States. Additionally, the knowledge initiatives of universities and professional associations institutionalized larger cultural ideas. At the very time that the modern higher education system began to form itself and at the time that modern professional associations began to create the system of scholarly communication, industry dominated.

For $19^{\text {th }}$-century American scientists more generally and for chemists in particular, their world was heavily influenced by the needs of a rapidly industrializing nation. Additionally, these scientists believed that the knowledge they were supposed to produce should be "useful." The universities in which scientists and chemists taught were attempting to expand their scientific offerings and meet the needs perceived by industry (Beardsley, 1964). The professional associations that these individuals joined had tied their own futures to the needs of these industries. Overall, these larger forces led to particular genres being produced in the documents of these scientists. They wrote articles that eschewed supposition and focused on facts and causes that could more easily be reproduced. These scientists sought out news from the very professional associations and universities that were attempting to meet the needs of the industrial United States.

Why are these developments important? Over time, the state became more involved with the work of scientists and universities. First, the U.S. Congress passed legislation like the Morrill Land Grant Act in the 19th century. Currently, federal funding through the National Science Foundation or other federal agencies continues to dominate the higher education landscape. Ferraris (2013) has suggested that these developments are something to which those involved in the system should pay attention because of "the state's first succumbing to bureaucratic documentality and then to informatics documentality" (p. 287). What is informatics documentality? According to Ferraris (2013), it is a way in which sovereign power is extended over a larger number of people. If indeed it is true that industry dominated the earlier bureaucratic documentality, at least in the United States, what does it mean that industry will continue to extend its influence through informatics documentality? The answer to that question is unclear, but its implications have tremendous consequences not only for the system of scholarly communication, but indeed for the future of science itself, as well. 


\section{Bibliography}

American Chemical Society (1876). Proceedings of the American Chemical Society.

Baatz, S. (1991). “'Squinting at Silliman:' Scientific Periodicals in the Early American Republic, 1810-1833," Isis, 82, no. 2 (1991): 223-244.

Beardsley, E. H. (1964). The Rise of the American Chemistry Profession, 18501900. Gainesville, FL: University of Florida Press.

Breneman, A. A. Ed. (1888). Journal of the American Chemical Society.

Browne, C. A., and Weeks, M. E. (1952). A History of the American Chemical Society: Seventy Five Eventful Years. Washington, D.C.: American Chemical Society.

Clark, W. (2006) Academic Charisma and the Origins of the Research University. Chicago: University of Chicago Press.

Ferraris, Maurizio (2013). Documentality. Translated by Richard Davies. New York: Fordham University Press.

Gibson, J. J. (1967). The Ecological Approach to Visual Perception. Hillsdale, N.J.: Laurence Erlbaum Associates.

Gross, A. G., Harmon, J. E., Reidy, M. (2002). Communicating Science: The Scientific Article from the $17^{\text {th }}$ Century to the Present. Oxford: Oxford University Press.

Harré, R. (2014). "New Tools for the Philosophy of Chemistry," HYLE International Journal for the Philosophy of Chemistry, 20, 77-91.

Kargon, R. H., and Knowles, S. G. (2002).. "Knowledge for Use: Science, Higher Learning, and America's New Industrial Heartland, 1880-1915." Annals of Science, 59, 1-20.

Kronick, D. A. (1976). A History of Scientific and Technical Periodicals: The Origins and Development of the Scientific Press, 1665-1790. Metuchen, NJ: Scarecrow Press.

Oleson, A., and Brown, S. C. Eds. (1976). The Pursuit of Knowledge in the Early American Republic: Scientific and Learned Societies from Colonial Times to the Civil War. Baltimore: Johns Hopkins University Press.

Philips, D. (2016). "Academies and Societies." In A Companion to the History of Science, edited by Bernard Lightman, 276-290. New York: Wiley.

Putnam, F. W. Ed. (1873). Proceedings of the American Association for the Advancement of Science.

Putnam, F. W. Ed. (1886). Proceedings of the American Association for the Advancement of Science.

Smith, J. L. (1874). "The Century's Progress in Industrial Chemistry," American Chemist, 5 (5), 61-70.

Shapin, S. (2008). The Scientific Life: A Moral History of a Late Modern Vocation. Chicago: University of Chicago Press. 
Silliman, B. (1874). “American Contributions to Chemistry," American Chemist, 5 (5), 70-114.

Silliman, B. (1874) "An Essay on American Contributions to Chemistry," American Chemist, 5 (6), 195-209.

Silliman, B. (1818). "The Plan of the Work," American Journal of Science, 1 (1), v-vi.

Silliman, B. (1886). Memoir of John Lawrence Smith, 1818-1883. Washington, D.C.: National Academy of Sciences.

Whitley, R. (1984). The Intellectual and Social Organization of the Sciences. Oxford: Clarendon Press. 